\section{PENGARUH POLA ASUH PEMBERIAN MAKAN TERHADAP KEJADIAN STUNTING PADA BALITA}

JKMA

Jurnal Kesehatan Masyarakat Andalas diterbitkan oleh:

Program Studi S-1 Kesehatan Masyarakat Fakultas Kesehatan Masyarakat Universitas Andalas p-ISSN 1978-3833 e-ISSN 2442-6725

14(2)3-11

@2020 JKMA

Disetujui 22 Juli 2020

Dipublikasikan 12 Agustus 2020 http://jurnal.fkm.unand.ac.id/index.php/jkma/

\title{
Dayuningsih $^{1}$, Tria Astika Endah Permatasari ${ }^{2}{ }^{凶}$, Nana Supriyatna ${ }^{3}$
}

\author{
${ }^{1}$ Mahasiswa Program Magister Fakultas Ilmu Keperawatan Universitas Muhammadiyah Jakarta; Dosen Akper RSPAD Gatot Subroto Jakarta \\ ${ }^{2}$ Dosen Fakultas Kedokteran dan Kesehatan Universitas Muhammadiyah Jakarta \\ ${ }^{3}$ Dosen Fakultas IImu Keperawatan Universitas Muhammadiyah Jakarta
}

\begin{abstract}
Abstrak
Prevalensi stunting secaca global di dunia termasuk di Indonesia masih tinggi. Pola asuh pemberian makan pada 1000 Hari Pertama Kehidupan memengaruhi asupan gizi yang berdampak langsung terhadap kejadian stunting. Tujuan penelitian untuk mengetahui faktor dominan yang mempengaruhi terjadinya stunting pada balita di wilayah kerja Puskesmas Kecamatan Senen, Provinsi DKI Jakarta. Penelitian menggunakan desain cross-sectional dilakukan di wilayah kerja puskesmas Kecamatan Senen pada bulan April 2019. Sampel sebanyak 182 ibu-balita diambil dengan teknik simple random sampling yang berasal dari 5 (lima) puskesmas kelurahan. Stunting diukur dengan antropometri menggunakan indikator tinggi badan menurut umur (TB/U). Variabel independen (pola asuh pemberian makan, tinggi badan Ibu, pemberian ASI eksklusif, berat badan lahir bayi, frekuensi konsumsi energi, dan riwayat penyakit infeksi) serta variabel dependen (stunting) dianalisis menggunakan regeresi logistik ganda. Stunting dialami oleh sebanyak 31,8\% (14,8\% balita sangat pendek dan $17,0 \%$ pendek). Faktor dominan yang berpengaruh terhadap kejadian stunting adalah pola asuh pemberian makan (OR: 6,496 95\% CI: 2,486-16,974). Balita yang memeroleh pola asuh pemberian makan yang kurang berisiko 6 kali lebih tinggi mengalami stunting dibandingkan balita yang pola asuh makannya baik. Perlu kebijakan terkait pengasuhan balita terutama bagi ibu bekerja seperti penyediaan fasilitas day care ditempat kerja sehingga dapat memperbaiki pola asuh pemberian makan.
\end{abstract}

Kata kunci: Balita, BBLR, Pola asuh pemberian makan, Stunting

THE IMPACT OF FEEDING PARENTING TOWARDS STUNTING AMONG CHILDREN UNDER FIVE YEARS OLD

\begin{abstract}
The prevalence of stunting globally in the world including in Indonesia is still high. Parenting in the First 1000 Days of Life, affects nutritional intake which has a direct impact on stunting. The study aimed to determine the dominant factors that influence stunting in children under five. A cross-sectional study was conducted in Senen District health center's working area in April 2019. A sample of 182 mothers and children under five was taken using a simple random sampling technique from 5 community health centers. Stunting was measured by anthropometry using height-for-age indicators. The independent variables (parenting style, mother's height, exclusive breastfeeding, baby's birth weight, frequency of energy consumption, and history of infectious diseases) and the dependent variable (stunting) were analyzed using multiple logistic regression. As many as $31.8 \%$ were stunting $(14.8 \%$ severe stunting and $17.0 \%$ stunting). The dominant factor influencing the stunting is feeding parenting (OR: 6.496 95\% CI: 2,486-16,974). Children who were given poor feeding parenting are 6 times more at risk stunted than children who have good parenting. Policies need to be related to caring for children under five, especially for working mothers such as the provision of daycare facilities in the workplace to improve parenting care.
\end{abstract}

Keywords: Feeding parenting, Low birth weight, Stunting

\section{$\triangle$ Korespondensi Penulis:}

Fakultas Kedokteran dan Kesehatan Universitas Muhammadiyah Jakarta

Jl. Cempaka Putih Tengah XXX No.27, Cemp. Putih Tim., Kec. Cemp. Putih, Kota Jakarta Pusat Email : astika.tria@gmail.com 


\section{Pendahuluan}

Stunting merupakan inidikator kegagalan pertumbuhan, dimana pertumbuhan tinggi badan balita tidak sesusi dengan usianya, yaitu z-score tinggi menurut umur (TB/U) lebih dari 2 standar deviasi di bawah median Standar Pertumbuhan Anak Organisasi Kesehatan Dunia. (1) Masalah kekurangan gizi kronis ini merupakan permasalahan yang semakin banyak ditemukan di negara berkembang, termasuk Indonesia. Menurut United Nations International Children's Emergency Fund (UNICEF) tahun 2013 satu dari tiga anak balita mengalami stunting. Kejadian stunting di Indonesia berdasarkan data dari UNICEF (2013) diperkirakan terjadi pada 7,8 juta balita. Hal ini menjadikan Indonesia termasuk dalam 5 (lima) besar negara yang memiliki prevalensi balita stunting tertinggi di dunia. Balita yang mengalami stunting menjadi beban bagi negara karena menjadikan Sumber Daya Manusia (SDM) yang berkualitas rendah karena mengalami kegagalan pertumbuhan dan perkembangan secara kronis. Balita stunting selain pendek yaitu pertumbuhan tinggi badan tidak sesuai usianya, memiliki kemampuan kognitif yang rendah, juga mengalami gangguan metabolisme yang berisiko terhadap terjadinya berbagai penyakit degenerative pada masa dewasa. ${ }^{(1)}$

Secara global, prevalensi stunting pada anak menurun dari 39,7\% tahun 1990 menjadi 26,7\% pada tahun 2010. Angka ini diperkirakan akan mencapai $21,8 \%$ pada tahun 2020. Prevalensi stunting di Afrika mengalami stagnasi sejak tahun 1990 sekitar 40\%, sementara di Asia menunjukkan penurunan dari $49 \%$ pada tahun 1990 menjadi 28\% pada tahun 2010. Prevalensi stunting di beberapa negara di Asia Tenggara juga masih tinggi seperti Myanmar (35\%), Vietnam (23\%), dan Thailand (16\%). (2) Di Indonesia, prevalensi stunting mengalami peningkatan dari 35,7\% (2010) menjadi 37\% (2013), dimana angka ini masuk dalam katergori prevalensi tinggi. ${ }^{(3)}$ Berbagai upaya percepatan perbaikan gizi secara nasional memberikan dampak positif terhadap penurunan prevalensi stunting. Data terbaru berdasarkan hasil Riset Kesehatan Dasar (Riskesdas) tahun 2018 melaporkan bahwa prevalensi stunt- ing menurun sekitar 6\% yaitu menjadi 30,8\%. ${ }^{(4)}$

Berdasarkan data Riskesdas (2018) juga dapat diketahui bahwa prevalensi stunting tinggi di berbagai provinsi baik. Prevalensi balita stunting di DKI Jakarta dari hasil Riskesdas tersebut mencapai 17,7\%. Angka ini hampir mencapai ambang batas prevalensi dengan kategori tinggi yang ditetapkan oleh WHO yaitu sebesar 20\%. Provinsi DKI Jakarta merupakan ibu kota negara yang memiliki ketersediaan pangan yang cukup dan beragam, akses terhadap pelayanan fasilitas kesehatan, dan sosial ekonomi masyarakat yang cukup tinggi dibandingkan provinsi lainnya dengan Upah Minimum Provinsi tertinggi dibandingkan provinsi lainnya. Selain itu, di provinsi ini akses terhadap informasi mengenai edukasi gizi dan kesehatan juga sangat mudah. ${ }^{(4)}$

Masalah stunting yang terjadi menggambarkan adanya masalah gizi kronis, dipengaruhi dari kondisi ibu atau calon ibu, masa janin dan masa bayi/balita, termasuk penyakit yang diderita selama masa balita. Seperti masalah gizi lainnya, tidak hanya terkait masalah kesehatan, namun juga dipengaruhi berbagai kondisi lain yang secara tidak langsung mempengaruhi kesehatan. Dampak stunting juga dapat mengganggu perkembangan mental dan kecerdasanya saat usia dewasa, dampak ini dapat terlihat dari ukuran fisik yang tidak optimal serta kualitas kerja yang tidak kompetitif yang berakibat pada rendahnya produktivitas ekonomi. Balita yang kekurangan gizi akan mengalami penurunan kecerdasan, penurunan imunitas dan produktivitas, masalah kesehatan mental dan emosional, serta kegagalan pertumbuhan..$^{(5,6)}$

Faktor langsung yang berhubungan dengan stunting yaitu asupan makanan dan status kesehatan. Asupan energi dan zat gizi yang tidak memadai, serta penyakit infeksi merupakan faktor yang sangat berperan terhadap masalah stunting.(7) Faktor tidak langsung yang berhubungan dengan stunting salah satunya pola pengasuhan, dalam hal ini yang sangat berhubungan adalah pola asuh pemberian makan. Berdasarkan penelitian yang dilakukan Renyoet, dkk didapatkan hasil adanya hubungan yang signifikan antara perhatian/ dukungan ibu terhadap anak dalam praktik pem- 
berian makanan, persiapan dan penyimpanan dengan kejadian stunting, maka dapat dikatakan ibu yang memberikan perhatian dan dukungan terhadap anak dalam hal ini akan memberikan dampak positif dalam keadaan status gizi. ${ }^{(8)}$ Berdasarkan hal tersebut maka tujuan penelitian ini adalah untuk mengetahui faktor yang mempengaruhi kejadian stunting pada balita di wilayah kerja Puskesmas Kecamatan Senen Jakarta Pusat.

\section{Metode}

Desain penelitian yang digunakan cross-sectional study. Penelitian ini dilakukan di wilayah kerja Puskesmas Kecamatan Senen Jakarta Pusat pada bulan Januari-Juni tahun 2019, dimana wilayah tersebut merupakan salah satu wilayah dengan kejadian stunting yang tinggi. Populasi dalam penelitian ini adalah seluruh balita di wilayah kerja Puskesmas Senen yang terdiri dari 5 Puskesmas Kelurahan. Besar sampel dihitung dengan menggunakan rumus uji hipotesis 1 (satu) proporsi populasi. Sampel diambil dengan teknik simple random sampling dan diperoleh sebanyak 182 ibu-balita yang memenuhi kriteria inklusi, yaitu: balita berusia 0-59 bulan yang lahir secara normal dan cukup bulan, tidak mengalami cacat bawaan (kongenital) dan menderita penyakit serius lainnya yang memengaruhi status gizi seperti thalasemia dan penyakit serius lainnya.

Data yang digunakan pada penelitian ini adalah data primer dan sekunder. Stunting diukur secara antropometri melalui pengukuran tinggi badan atau panjang badan menurut umur $(\mathrm{PB} / \mathrm{U}$ atau $\mathrm{TB} / \mathrm{U})$. Panjang badan diukur dengan lengthboard yang terserdia di Posyandu (standar WHO), sedangkan tinggi badan menggunakan microtoise dengan ketelitian $0,1 \mathrm{~cm}$. Selanjutnya, kategori stunting dianalisis dengan WHO-anthro dan dibagi menjadi 3 (tiga) yaitu: 1) 'sangat pendek', jika nilai <-3 SD, 2) 'pendek', jika nilai $-3 \mathrm{~s} / \mathrm{d}<-2 \mathrm{SD}$, dan 3) 'normal', jika nilai $>-2 \mathrm{SD}$.

Pola asuh pemberian makan pada penelitian ini diadopsi dari penelitian Astuti terdiri dari 24 pertanyaan mengenai pola asuh ibu dalam memberikan makan kepada balitanya. ${ }^{(9)}$ Kemudian dilakukan uji validitas dan realibili- tas dengan nilai cronbach's alpha 0,361. Setelah itu pola asuh pemberian makan dikategorikan menjadi 2 yaitu rendah (jika skor <62) dan tinggi (jika >62). Frekuensi konsumsi energi dan protein diukur dengan menggunakan metode food formulir questionnaire (FFQ) dari Gibson yang terdiri dari 4 (empat) kelompok makanan yaitu sumber energi, sumber protein hewani, sumber protein nabati serta susu dan produknya, selanjutnya dikategorikan menjadi 2 (dua) yaitu frekuensi konsumsi rendah dan tinggi berdasarkan nilai median. ${ }^{(10)}$ Selain itu data karakteristik ibu dan balita diperoleh melalui kuesioner terstruktur. Data sekunder yang digunakan yaitu mencakup data BBL (Berat Badan Lahir) dan riwayat penyakit infeksi diperileh melalui data balita yang terdapat di puskesmas serta data yang terdapat di buku Kesehatan Ibu dan Anak/KIA setiap balita.

Data dianalisis secara bivariat untuk mengetahui hubungan antara variabel terikat dan variabel bebas Sedangkan analisis multivariat dipakai untuk mengetahui nilai OR (Odd Ratio). Analisis bivariat yang digunakan adalah uji chi square, sedangkan analisis multivariat yang digunakan adalah regresi logistik dengan program SPSS. Penelitian ini sudah mendapatkan izin pelaksanaan penelitian oleh PTSP DKI Jakarta wilayah Jakarta Pusat dan uji etik oleh Komite Etik FIK UMJ dengan Nomor 0306/F.9-UMJ/II/2019 yang diterbitkan pada bulan Februari tahun 2019.

\section{Hasil}

Hasil penelitian ini, yaitu dilakukan di di Wilayah Kerja Puskesmas Kecamatan Senen Jakarta Pusat menunjukkan dari 182 balita, terdapat sebesar 31,8\% balita stunting yaitu dimana 14,8\% balita 'sangat pendek' dan 17,0\% 'pendek' (Tabel 1). Menurut WHO, jika suatu wilayah memiliki prevalensi stunting melebihi 20\%, termasuk dalam ketegori tinggi. Dengan demikian, prevalensi stunting di wilayah ini masih tinggi. ${ }^{(11)}$ Kondisi ini sejalan dengan masih banyaknya ibu yang memberikan pola asuh pemberian makan yang kurang terhadap balita yaitu sebesar 48,9\%. Berdasarkan hasil penelitian ini, mayoritas ibu mengaku telah berusaha keras untuk menyuruh 
anak makan (84.6\%) dan hampir seluruh ibu (96.7\%) menyuapi anaknya saat makan. Sebagian besar ibu memberikan pujian jika anak mau menghabiskan makanannya (70\%) dan sebaliknya bahwa sebagian besar ibu juga akan memberikan hukuman terhadap anak jika tidak mau makan (72.5\%). Contoh hukuman yang umum ibu berikan kepada anak yaitu dengan cara melarang anak untuk bermain begitupun sebaliknya (Tabel 2).

Tabel 1. Gambaran Kejadian Stunting pada Balita dan \ Karakteristik Ibu

\begin{tabular}{ccc}
\hline Variabel & Jumlah & Persentase \\
$(\mathrm{n})$ & \begin{tabular}{c} 
Po) \\
\hline
\end{tabular}
\end{tabular}

Stunting

- Sangat Pendek

- Pendek

- Normal 31

Pendidikan ibu

- $\mathrm{SD}$

- SMP

- SMA

94

- Diploma

- Sarjana

Penghasilan Keluarga

- Rendah

- Tinggi

Tinggi Badan Ibu

- Pendek

- Normal

Pola Asuh

- Rendah

- Tinggi

ASI Eksklusif

- $\mathrm{Ya}$

- Tidak

Imunisasi Dasar Lengkap

- Tidak diimunisasi

- Ya, tidak lengkap

- Ya lengkap

BBLR

- Ya
Frekuensi Konsumsi Energi

- Rendah 78 42,9

- Tinggi 104

Frekuensi Konsumsi Protein

- Rendah

- $\quad$ Tinggi 50,0

Penyakit Infeksi

- Pernah 126

- Tidak Pernah

56

30,8

Tabel 2. Pola Asuh Pemberian Makan Pada Balita

\begin{tabular}{lccc}
\hline No & Pernyatan & Ya & Tidak \\
& $\%$ & $\%$ \\
\hline
\end{tabular}

Demandingness/kontrol perilaku dari orang tua

1 Ibu berusaha dengan keras untuk 84,6 menyuruh anak makan

2 Ibu berusaha mengingatkan anak untuk makan ,jika tidak mau makan ,ibu akan menjauhkan dari makanan lain (" jika kamu tidak mau makan sayur,ibu tidak akan memberikan buah")

3 Ibu Menjanjikan sesuatu (selain makanan) jika anak bersedia makan ("Jika kamu mau makan nanti ibu ajak ke taman ")

4 Ibu Menyuapi anak saat makan

$96,7 \quad 3,3$

5 Ibu mengatakan kepada anak agar memakan makanan yang tersedia dipiring walaupun sedikit

6 Ibu menunjukan ketidaksetujuan (tidak berkenan) ketika anak menolak makan

7 Ibu Menjelaskan (menasehati) kepada anak kenapa harus makan ("Susu baik untuk kesehatanmu karena dapat membuat tulangmu kuat")

8 Ibu mengatakan kepada anak untuk makan sesuatu yang ada diatas piring ("makan nasimu ")

9 Ibu mengatakan kepasa anak untuk menyegerakan makan (" ayo cepat dimakan nasinya")

10 Jika anak tidak mau makan,ibu memberi peringatan tentang sesuatu yang lain selain makanan ("Jika kamu tidak menghabiskan makananmu ,tidak ada waktu main ")

11 Ibu mendorong anak agar anak mau makan dengan menggunakan makanan sebagai hadiah ("Jika kamu menghabiskan sayurmu,nanti ibu berikan buah ")

12 Ibu meminta (memohon) pada anak untuk makan ("ayo makan, nanti

59,3

40,7 
13 Ibu mengatakan sesuatu yang positif tentang makanan yang dimakan anak selama anak makan

14 Ibu menata makanan untuk membuat makanan lebih menarik

15 Ibu mengajukan pertanyaan pertanyaan kepada anak tentang makanan (menanyakan makanan kesukaan anak )

16 Ibu berunding dengan anak agar mau makan

17 Ibu memperbolehkan anak memilih makanan yang sesuai dengan kesukaanya

B Responsiveness/respon orang tua kepada anak

18 Ibu membantu anak untuk makan (memotong makanan menjadi bagian yang lebih kecil)

19 Ibu memberi pujian kepada anak ketika mau makan ( "anak pintar !kamu menghabiskan makananmu"

20 Ibu menunggu memberikan makanan tambahan sampai anak menyelesaikan makanan yang ada dipiringnya

21 Ibu menawari anak untuk menambah porsi makan yang ke-2

22 Ibu mengambilkan porsi makan yang ke-2 untuk anak

23 Ibu mendorong anak untuk mencoba makanan baru

24 Ibu memperbolehkan anak mengambilkan makananya sediri
$56,0 \quad 44,0$

56,0

44,0

$58,2 \quad 41,8$

$37,9 \quad 62,1$

$61,5 \quad 38,5$

$65,4 \quad 34,6$

$69,8 \quad 30,2$

$61,5 \quad 38,5$

$51,1 \quad 48,9$

$49,5 \quad 50,5$

$48,9 \quad 51,1$

$48,9 \quad 51,1$

Berdasarkan hasil studi ini juga dapat diperoleh gambaran karakteristik responden yaitu terdapat Hampir separuh dari 182 ibu balita pada penelitian ini memiliki tinggi badan kurang dari 150 centimeter $(40,9 \%)$. Pendidikan ibu tertinggi prevalensinya yaitu SMA (51,6\%), dengan demikian lebih dari separuh ibu memiliki pendidikan yang tinggi. Sebagian besar ibu berasal dari kelaurga dengan sosial ekonomi rendah dimana penghasilan keluarga umumnya $<\mathrm{UMR}(\leq \mathrm{R} p$. 3.900.000). Balita yang memeroleh ASI eksklusif pada peneltiian ini menurut jawaban ibu yaitu sebanyak 94,5\% dan telah memeroleh imunisasi dasar lengkap sebanyak 87,4\%. Terdapat 9,9\% balita yang lahir kurang dari 2500 gram (BBLR) dan sebanyak 69,2\% pernah menderita penyakit infeksi yaitu diare dan Infeksi Saluran Pernafasan Akut (ISPA). Asupan makanan balita masih tergolong rendah balita yang memiliki frekuensi konsumsi energi dan protein yang rendah yaitu masing-masing 42,9\% dan 50\% (Tabel 1).

Hasil analisis chi-square didapatkan bahwa dari 7 (tujuh) variabel bebas, terdapat 2 (dua) variabel yang tidak berhubungan signifikan terhadap terjadinya stunting (nilai $\mathrm{p}>0.05$ ) yaitu tinggi badan ibu dan pemberian ASI eksklusif (Tabel 3). Selanjutnya, berdasarkan hasil seleksi kandidat, hanya variabel pemberian ASI eksklusif yang tidak masuk dalam analisis selanjutnya yaitu analisis multivariat dengan regresi logistic ganda. Selebihnya yaitu variabel tinggi badan ibu, berat badan lahir rendah, pola asuh pemberian makan, frekuensi konsumsi energi, frekuensi konsumsi protein dan riwayat penyakit infeksi masuk dalam analisis multivariat $(\mathrm{p}<0,25)$. Model akhir uji regresi logistik menunjukkan risiko kejadian stunting pada balita yang paling dominan adalah pola asuh pemberian makan ( $\mathrm{p}$ value $=0,000$; oods ratio $=6,496 ; 95 \% \mathrm{CI}=2,486-16,974)$. Balita yang memeroleh pola asuh pemberian makan yang rendah berisiko 6 (enam) kali lebih besar mengalami kejadian stunting dibandingkan balita yang memeroleh pola asuh pemberian makan yang baik (Tabel 4).

Tabel 3. Hubungan Karakteristik Ibu dengan Kejadian Stunting pada Balita

\begin{tabular}{|c|c|c|c|}
\hline \multirow{2}{*}{ Karakteristik Subjek } & Stunting & Normal & \multirow{2}{*}{ p-value } \\
\hline & $\%$ & $\mathbf{n}$ & \\
\hline
\end{tabular}

Tinggi Badan Ibu

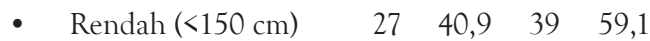

- $\quad$ Tinggi $(>150 \mathrm{~cm}) \quad 31 \quad 26,7 \quad 85 \quad 73,3$

ASI Eksklusif

- Tidak

- Ya

$4 \quad 40,0 \quad 6 \quad 60,0$

BBLR

- Ya

$\begin{array}{llll}54 & 31,4 & 118 & 68,6\end{array}$

0,728

- Tidak

$\begin{array}{llll}11 & 61,1 & 7 & 38,9\end{array}$

$\begin{array}{llll}47 & 28,7 & 117 & 71,3\end{array}$

Pola Asuh Pemberian

Makan

$\begin{array}{llllll}\text { - Rendah } & 45 & 50,6 & 44 & 49,4 & \\ \text { - Tinggi } & 13 & 14,0 & 80 & 86,0 & 0,000\end{array}$

Frekuensi Konsumsi

Energi 


\begin{tabular}{llllll} 
- Rendah & 34 & 43,6 & 44 & 56,4 & 0,005 \\
- Tinggi & 24 & 23,1 & 80 & 76,9 & \\
$\begin{array}{l}\text { Frekuensi Konsumsi } \\
\text { Protein }\end{array}$ & & & & & \\
- $\quad$ Rendah & 42 & 46,2 & 49 & 53,8 & \\
- $\quad$ Tinggi & 16 & 17,6 & 75 & 82,4 & 0,000 \\
Riwayat Penyakit Infeksi & & & & & \\
- Pernah & 49 & 38,9 & 77 & 61,1 & 0,004 \\
- Tidak Pernah & 9 & 16,1 & 47 & 83,9 & \\
\hline
\end{tabular}

Tabel 4. Hasil Uji Regresi Logistik Risiko Kejadian Stunting pada Balita

\begin{tabular}{lccc}
\hline \multicolumn{1}{c}{ Variabel } & p-value & OR & 95\% CI \\
\hline Tinggi Badan Ibu & 0,245 & 1,650 & $0,709-3,843$ \\
BBLR & 0,037 & 3,567 & $1,079-11,796$ \\
$\begin{array}{l}\text { Pola Asuh Pemberian } \\
\text { Makan }\end{array}$ & 0,000 & 6,496 & $2,486-16,974$ \\
$\begin{array}{l}\text { Frekuensi Konsumsi } \\
\text { Energi }\end{array}$ & 0,007 & 2,784 & $1,318-5,883$ \\
$\begin{array}{l}\text { Frekuensi Konsumsi } \\
\text { Protein }\end{array}$ & 0,853 & 1,089 & $0,440-2,698$ \\
$\begin{array}{l}\text { Riwayat Penyakit } \\
\text { Infeksi }\end{array}$ & 0,254 & 1,722 & $0,677-4,377$ \\
Constant & 0,001 & 0,107 & \\
\hline
\end{tabular}

\section{Pembahasan}

Kejadian stunting pada balita dipengaruhi oleh berbagai faktor. Salah satu faktor yang berperan adalah genetik meskipun berbagai penelitian menunjukkan bahwa faktor lingkungan lebih dominan dalam menyebabkan stunting. Salah satu faktor genetik yang berperan terhadap terjadinya stunting adalah tinggi badan ibu. Penelitian Nasikhah \& Margawati (2012) membuktikan bahwa tinggi badan ibu berpengaruh terhadap kejadian stunting pada balita. ${ }^{(12)}$ Begitupun hasil serupa dilaporkan oleh Fitriahadi (2018) di Puskesmas Wonosari bahwa tinggi badan ibu atau orang tua merupakan faktor penyebab terjadinya stunting. (13)

Faktor lingkungan lebih berpengaruh terhadap terjadinya stunting pada balita. Stunting secara langsung dapat disebabkab oleh asupan makanan dan terjadinya penyakit infeksi dimana kedua faktor tersebut sangat dipengaruhi oleh pola asuh ibu. Kecukupan asupan makanan sejak terutama pada 1000 Hari Pertama Kehidupan
(1000 HPK) yaitu periode kehamilan hingga bayi berusia 2 (dua) tahun berpengaruh terhadap status gizi balita. Setelah bayi dilahirkan, pemberian ASI eksklusif merupakan periode penting yang dapat mencegah terjadinya stunting dimana ASI mengandung seluruh zat gizi ideal yang diperlukan bayi. Keberhasilan ASI tersebut diawali dengan pemberian Inisiasi Menyusu Dini (IMD), yaitu pemberian ASI segera pada satu jam pertama setelah bayi dilahirkan. ${ }^{(14)}$ Keberhilan pemberian ASI tersebut akan lebih kuat jika ibu telah memiliki niat atau intensi untuk menyusui bayinya saat periode kehamilan. ${ }^{(15-16)}$ Namun, pada penelitian ini tidak menunjukkan adanya hubungan bermakna antara pemberian ASI eksklusif dengan kejadian stunting. Hal ini didukung oleh penelitian Vaozia dan Nuryanto (2016) bahwa riwayat ASI eksklusif bukan merupakan faktor risiko kejadian stunting. ${ }^{(17)}$ Meskipun demikian, penelitian lainnya yang dilakukan oleh Ni'mah dan Nadhiroh menunjukkan bahwa terdapat hubungan antara pemberian ASI eksklusif dengan kejadian stunting. Kebutuhan zat gizi pada usia 0-6 bulan dapat dipenuhi dari ASI. Anak yang tidak mendapatkan ASI eksklusif berisiko lebih tinggi untuk kekurangan zat gizi yang diperlukan untuk proses pertumbuhan. ${ }^{(18)}$

Stunting dipengaruhi oleh BBLR. Hal ini sesuai dengan penelitian sebelumnya yang dilakukan oleh Nasution, et al (2014) menyatakan bahwa balita yang lahir dengan BBLR 5,6 kali lebih beresiko untuk mengalami kejadian stunting dibandingkan anak yang lahir dengan berat badan normal. Kondisi ini dapat terjadi karena pada bayi yang lahir dengan BBLR, sejak dalam kandungan telah mengalami retardasi pertumbuhan intrauterin dan akan berlanjut sampai usia selanjutnya setelah dilahirkan yaitu mengalami pertumbuhan dan perkembangan yang lebih lambat dari bayi yang dilahirkan normal. ${ }^{(19)}$

Faktor yang paling dominan berpengaruh terhadap kejadian stunting pada penelitian ini adalah pola asuh pemberian makan. Hal ini sejalan dengan penelitian Renyoet, et al (2012) yang menunjukkan bahwa ada hubungan yang signifikan antara pola asuh dengan kejadian stunting pada balita. ${ }^{(8)}$ Namun hal ini tidak sejalan dengan 
penelitian Hayyudini, et al (2017) di Kota Semarang menunjukkan bahwa tidak ada hubungan yang signifikan antara pola asuh keluarga dengan status gizi anak. Perilaku ibu mencakup pemberian ASI dan pemberian makan pendamping ASI (MP-ASI), cara makan yang sehat, memberi makanan yang bergizi dan mengontrol besar porsi yang dihabiskan akan meningkatkan status gizi anak. ${ }^{(20)}$ Perilaku ibu dalam menjaga kesehatan balita dipengaruhi oleh pengetahuan dimana paparan terhadap pengetahuan tersebut ditentukan oleh informasi yang diperolehnya dari lingkungan baik media massa ataupun media sosial, kader, maupun tenaga kesehatan. Salah satu upaya yang telah dilakukan adalah melalui penguatan kapasitas kader di tingkat komunitas dalam melakukan upaya sosialisasi mengenai pencegahan stunting pada ibu balita di Provinsi Kalmantan Tengah (2019). ${ }^{(21)}$ Selain itu, dukungan keluarga merupakan faktor utama yang memengaruhi perilaku ibu dalam dalam pengambilan suatu keputusan untuk meningkatkan kesehatan balita seperti pemberian imuniasasi, disamping pemberian asupan makanan. (22)

Kejadian stunting disebabkan oleh kurangnya asupan makanan termasuk kekurangan asupan energi dan protein. Peneltiian Nabuasa, et al (2013) di Nusa Tenggara Timur menunjukkan adanya hubungan yang bermakna antara asupan energi dengan kejadian stunting. Asupan energi tidak mencukupi kebutuhan akan terjadi gangguan pertumbuhan pada anak salah satunya stunting. ${ }^{(23)}$ Namun penelitian Bening, et al (2016) di Semarang menunjukkan hasil yang berbeda, yaitu tidak ada hubungan yang bermakna antara tingkat kecukupan energi dengan risiko kejadian stunting. Hal ini disebabkan frekuensi konsumsi energi balita pada penelitian tersebut relatif lebih homogen dibandingkan dengan penelitian ini. ${ }^{(24)}$ Selain itu, pada penelitian ini menunjukkab adanya hubungan yang bermakna antara konsumsi protein dengan kejadian stunting. Hasil ini sejalan dengan penelitian Sari, et al (2016) yang menunjukkab bahwa balita dengan asupan protein rendah lebih berisiko 1,87 kali mengalami stunting dibandingkan dengan balita yang memiliki asupan protein cukup. ${ }^{(25)}$ Ses- eorang yang mengkonsumsi protein dengan nilai gizi yang rendah akan menunjukan gejala-gejala kekurangan gizi. Gangguan gizi termasuk stunting disebabkan oleh kurangnya konsumsi makanan secara kuantitas dan kualitas.

Selain asupan makakan, kejadian stunting pada balita juga dipengaruhi oleh adanya penyakit infeksi. Penelitian Nabuasa, et al (2013) menunjukkan bahwa terdapat hubungan penyakit infeksi dengan kejadian stunting. ${ }^{(23)}$ Namun hasil yang berbeda diperoleh Wellina yang mengatakan bahwa riwayat penyakit infeksi diare dan ISPA bukan faktor risiko stunting pada anak umur 12-24 bulan. ${ }^{(26)}$ Tingginya jumlah anak yang menderita penyakit infeksi saluran pernapasan akut (ISPA) dan diare disebabkan sanitasi dan kondisi rumah yang tidak sesuai. Hal ini sering terjadi di pemukiman padat dan kumuh seperti beberapa wilayah di Kecamatan Senen tempat pengambilan sampel penelitian ini.

\section{Ucapan Terima Kasih}

Peneliti mengucapkan terima kasih kepada Kepala Dinas Kesehatan DKI Jakarta, Kepala Puskesmas Kecamatan Senen. Ucapan terima kasih juga disampaikan kepada Dekan Fakultas Ilmu Keperawatan Universitas Muhammadiyah Jakarta, seluruh tim pengumpul data, serta semua pihak yang turut berpartisipasi pada penelitian ini.

\section{Simpulan}

Faktor yang berhubungan bermakna atau mempengaruhi kejadian stunting pada balita adalah BBLR, pola asuh pemberian makan dan frekuensi konsumsi energi. Faktor yang paling dominan berhubungan dengan kejadian stunting pada balita adalah pola asuh pemberian makan. Balita dari ibu dengan pola asuh pemberian makan yang rendah cenderung 6 kali lebih tinggi menyebabkan kejadian stunting pada balita dibandingkan ibu dengan pola asuh pemberian makan tinggi.

\section{Rekomendasi}

Kebijakan terkait pengasuhan balita diperlukan terutama bagi ibu bekerja seperti penye- 
diaan fasilitas day care ditempat kerja sehingga dapat memperbaiki pola asuh pemberian makan.

\section{Daftar Pustaka}

1. World Health Organization. Global Nutrition Targets 2025: Stunting policy brief. Geneva: 2018.

2. de Onis M, Blossner M, Borghi E. Prevalence and trends of stunting among pre-school children, 1990-2020. Public Health Nutrition. 2012;15(1):142-148.

3. Kementerian Kesehatan Republik Indonesia. Riset Kesehatan Dasar 2013. Jakarta: Badan Penelitian dan Pengembangan Kesehatan, Departemen Kesehatan, Republik Indonesia; 2013.

4. Kementerian Kesehatan Republik Indonesia. Riset Kesehatan Dasar 2018. Jakarta: Badan Penelitian dan Pengembangan Kesehatan, Departemen Kesehatan, Republik Indonesia; 2018.

5. 5. Sunny BS, DeStavola B, Dube A, Kondowe S, Crampin AC, Glynn JR. Does early linear growth failure influence later school performance? A cohort study in Karonga district, northern Malawi. PLoS ONE. 2018 November 5; 13(11): 1-15. DOI:10.1371/journal. pone. 0200380

6. Asiki G, Newton R, Marions L, Kamali A, Smedman L. The effect of childhood stunting and wasting on adolescent cardiovascular diseases risk and educational achievement in rural Uganda: a retrospective cohort study. Global Health Action. 2019; 12(1):1-10. DOI: 10.1080/16549716.2019.1626184

7. Souganidis E. The relevance of micronutrients to the prevention of stunting. Sight Life 2012; 26(2): 10-18.

8. Renyoet BS, Hadju V, Rachmiwati SN. Hubungan pola asuh dengan kejadian stunting anak usia 6-23 bulan di wilayah pesisir kecamatan Tallo kota Makassar tahun 2013. Jurnal Nutrient Science (PA-NSC). 2012; 1-13.

9. Astuti WT. Hubungan pola asuh pemberian makan dan perilaku makan dengan kejadian obesitas pada anak pra sekolah di kota Magelang. [Tesis] Yogyakarta: Universitas
Gadjah Mada; 2014.

10. Gibson RS. Principles of nutritional assessment. 2nd ed. New York: Oxford University Press; 2005.

11. WHO. Nutrition Landscape Information System: Country Profile Indicator, Interpretation Guide. Geneva: World Health Organization; 2012.

12. Nasikhah R, Margawati A. Faktor risiko kejadian stunting pada balita usia 24-36 bulan di kecamatan Semarang Timur. Journal of Nutrition College. Oktober 2012;1(1):176-184. DOI:10.14710/jnc.v1i1.738

13. Fitriahadi E. Hubungan tinggi badan ibu dengan kejadian stunting pada balita usia 24-59 bulan. Jurnal Keperawatan dan Kebidanan Aisyiyah. Juni 2018;14(1):15-24. DOI:10.31101/ jkk.545

14. Permatasari TAE, Syafruddin A. Early initiation of breastfeeding related to exclusive breastfeeding and breastfeeding duration in rural and urban areas in Subang, West Java, Indonesia. J Health Res. 2016;30(5):337-45. DOI: $10.14456 /$ jhr.2016.46

15. Permatasari TAE, Sartika RAD, Achadi EL, Purwono U, Irawati A, Ocviyanti D, et al. Breastfeeding intention among pregnant women. Kesmas: National Public Health Journal. 2018;12(3):134-141. DOI:10.21109/ kesmas.v12i3.1446

16. Permatasari TAE, Sartika RAD, Achadi EL, Purwono U, Irawati A, Ocviyanti D, et al. Does breastfeeding intention among pregnant mothers associated with early initiation of breastfeeding?. Jurnal Kesehatan Reproduksi. 2016; 7(3):169-184.

17. Vaozia S, Nuryanto. Faktor risiko kejadian stunting pada anak usia 1-3 tahun (studi di desa Menduran kecamatan Brati kabupaten Grobogan). Journal of Nutrition College. Oktober 2016;5(4):314-320. DOI:10.14710/jnc. v5i4.16426

18. Ni'mah K, Nadhiroh SR. Faktor yang berhubungan dengan kejadian stunting pada balita. Media Gizi Indonesia. 2015;10(1):13-19. DOI:10.20473/mgi.v10i1.13-19

19. Nasution D, Nurdiati, DS, Huriyati E. Berat 
badan lahir rendah (BBLR) dengan kejadian stunting pada anak usia 6-24 bulan. Jurnal Gizi Klinik Indonesia. Juli 2014; 11(1), 31-37. DOI: $10.22146 /$ ijcn.18881

20. Hayyudini D, Suyatno, Dharmawan Y. Hubungan karakteristik ibu, pola asuh dan pemberian imunisasi dasar terhadap status gizi anak usia 12-24 bulan (studi di wilayah kerja Puskesmas Kedungmundu Kota Semarang tahun 2017). Jurnal Kesehatan Masyarakat. 1 Oktober 2017;5(4):788-800.

21. Permatasari TAE, Chairunnisa, Herlina L. Penguatan kapasitas kader melalui gerakan 'aisyiyah sehat (grass) sebagai upaya pencegahan penyakit tidak menular dan stunting, serta peningkatan kesehatan ibu dan anak di Provinsi Kalimantan Tengah. Prosiding Seminar Nasional Pengabdian Masyarakat Lembaga Penelitian dan Pengabdian kepada Masyarakat Universitas Muhammadiyah Jakarta. 2019. 24 September (1): 1-4. http://jurnal. umj.ac.id/index.php/semnaskat

22. Pendit SA, Permatasari TAE, Supriyatna N. Analisis pengaruh dukungan keluarga, dan faktor lainnya terhadap pemberian imunisasi MR pada balita. Jurnal Keperawatan Silampari. Desember 2019; 3(1): 322-331. Https:// doi.org/10.31539/jks.v3i1.848

23. Nabuasa CD, Juffrie M, Huriyati E. Riwayat pola asuh, pola makan, asupan zat gizi berhubungan dengan stunting pada anak 24-59 bulan di Biboki Utara, Timor Tengah Utara, Nusa Tenggara Timur. Jurnal Gizi dan Dietetik Indonesia. September 2013; 1(3):151-163. DOI: 10.21927/ijnd.2013.1(3).151-163.

24. Bening S, Margawati A, Rosidi A. Asupan gizi makro dan mikro sebagai faktor risiko stunting anak usia 2-5 tahun di Semarang. Jurnal Medica Hospitalia. November 2016;4(1):4550. DOI: $10.36408 / \mathrm{mhjcm} . v 4 i 1.245$

25. Sari EM, Juffie M, Nurani N, Sitaresmi MN. Asupan protein, kalsium dan fosfor pada anak stunting dan tidak stunting usia 24-59 bulan. Jurnal Gizi Klinik Indonesia. April 2016;12(4):152-159. DOI:10.22146/ ijcn.23111

26. Wellina WF, Kartasurya MI, Rahfiludin MZ.
Faktor risiko stunting pada anak umur 12-24 bulan. Jurnal Gizi Indonesia. 30 Desember 2016;15(1):55-61. DOI:10.14710/jgj.5.1.55-61 